\title{
Nezavisna kulturna scena kao akter promjena u urbanom prostoru: primjer Zadra
}

\author{
Željka Tonković \\ Sveučilište u Zadru, Odjel za sociologiju, Hrvatska \\ e-mail: zeljka.tonkovic@unizd.hr
}

\author{
Hrvoje Pašalić \\ e-mail:hrvoje.pasalic@gmail.com
}

SAŽETAK U radu se donose rezultati istraživanja nezavisne kulturne scene u Zadru, pri čemu su $\mathrm{u}$ fokusu rada prostorni aspekti djelovanja u polju nezavisne kulture. Kontinuirana nastojanja aktera scene da ostvare pravo na prostor, a time i pravo na grad, u ovom se radu sagledavaju iz teorijske perspektive kritičke urbane teorije. Sukladno njezinom kulturno-umjetničkom i društvenom djelovanju, a koje nerijetko odlikuju aktivističke i progresivne prakse, nezavisnu kulturnu scenu u ovom se radu sagledava kao specifičan tip civilnih urbanih aktera. Svrha istraživanja bila je steći uvid u različite aspekte borbe za ostvarivanje prava na prostor djelovanja, i to iz perspektive predstavnika scene. Istraživanje je provedeno tehnikom polustrukturiranog intervjua te je obuhvatilo dvadeset i jednog sugovornika. Na temelju kodiranja podataka, koje se odvijalo na deskriptivnoj, tematskoj i analitičkoj razini, rezultati istraživanja organizirani su u tri tematske cjeline: prostor kao upotrebni resurs, prostor kao tržišni resurs te uloga javnih politika. Rezultati istraživanja pokazuju da se kroz prostornu problematiku nezavisne kulture ocrtavaju širi mehanizmi odnosa prema prostornim resursima i prostoru kao javnom dobru, što dodatno potvrđuje njezinu društvenu relevantnost.

Ključne riječi: nezavisna kulturna scena, pravo na grad, urbani akteri, Zadar. 


\section{Uvod}

Nedostatak adekvatnog prostora za djelovanje jedan je od temeljnih problema s kojima se suočavaju brojne udruge, organizacije i kolektivi koji djeluju u okvirima onoga što se uvriježeno naziva „nezavisna kulturna scena“. Premda definiranje pojma nezavisne kulture nije lišeno određenih prijepora, taj se pojam, prema Višnić (2008.:10), odnosi na sve one kulturne aktere koji „nisu osnovani od strane državnih ili nekih drugih vanjskih tijela, $[\ldots]$ koji samostalno definiraju svoje organizacijske strukture, tijela i procese odlučivanja i upravljanja i [...] koji financijski i programski ne ovise isključivo o državi ili nekom trećem subjektu “. ${ }^{1}$ Drugim riječima, nezavisnu kulturnu scenu pretežno čine udruge i organizacije civilnog društva u području suvremene kulture i umjetnosti, a čije djelovanje obilježavaju društveno angažirane, aktivističke i progresivne umjetničke prakse, preispitivanje institucionalnih okvira djelovanja u kulturnom polju te uspostavljanje novih modela kolektivnog djelovanja, uključujući taktičko umrežavanje u svrhu poboljšavanja uvjeta rada. U odnosu spram javnog sektora u kulturi, udruge i organizacije na nezavisnoj sceni nalaze se u marginaliziranom položaju, što za posljedicu ima trajnu nesigurnost njihova djelovanja, a takav se odnos prema nezavisnoj sceni može pratiti još od vremena njezina uspostavljanja 1990-ih godina (Tonković i Sekelj, 2018.; Vidović, 2010.). Osim financijske nesigurnosti, nedostatak prostora za djelovanje izravna je posljedica neravnopravnog položaja nezavisne scene unutar kulturnog sustava.

Djelujući izvan dominantnih tokova kulturnog, gospodarskog i društveno-političkog polja, organizacije nezavisne kulture sa sjedištem izvan glavnoga grada nerijetko se suočavaju s dodatno otežavajućim čimbenicima, uključujući potkapacitiranost civilnog sektora, slabije razvijenu kulturnu infrastrukturu i nedostatno ulaganje u kulturu na lokalnoj razini. Takve se okolnosti mogu povezati s procesom kulturne centralizacije, koji je u Hrvatskoj vidljiv u neravnomjernoj geografskoj distribuciji kulturnih ustanova (Šakaja, 1999.), kulturnih i kreativnih industrija (Primorac, 2008.), udruga i organizacija civilnog društva na području suvremene kulture i umjetnosti (Barada, Primorac i Buršić, 2016.), a posljedično i u regionalnim razlikama u kulturnoj participaciji i potrošnji (Tonković, Marcelić i Krolo, 2017.). U kontekstu nezavisne kulturne scene grada Zadra, prethodna istraživanja (Tonković, 2012.; Tonković i Pepić, 2013.) prepoznala su nedostatak adekvatnih prostora za djelovanje kao jednu od ključnih prepreka ostvarivanju njenog punog potencijala. No, s obzirom na dosadašnji izostanak sustavnog istraživačkog pristupa spomenutom problemu, a u svrhu njegovog boljeg razumijevanja, ovim istraživanjem težilo se detektiranju percepcije reperkusija mehanizama prostornog upravljanja po djelovanje ovog kulturnog polja. Oslanjajući se na kvalitativnu istraživačku metodologiju, rad donosi uvid u djelovanje i perspektive aktera nezavisne kulture u kontekstu njihove borbe za prostor. Prvi dio rada donosi

\footnotetext{
${ }^{1}$ Više o prijeporima oko naziva ovog kulturnog polja vidjeti u: Vidović (2012.).
} 
pregled teorijsko-konceptualnog polazišta, dok se u drugom dijelu rada iznose rezultati kvalitativnog istraživanja koje je organizirano u tri tematske cjeline: prostor kao upotrebni resurs, prostor kao tržišni resurs te uloga javnih politika, koje su proizašle iz procesa kodiranja podataka.

\section{Teorijsko polazište}

Istraživanjem u podlozi ovog rada pokušalo se steći kompleksniji uvid u jedan od gorućih problema zadarske nezavisne kulturne scene - dugogodišnji nedostatak adekvatnih prostora za djelovanje. Spomenuti problem pritom se nastojalo sagledati u svjetlu dubljih mehanizama prostornog upravljanja, koji potpomažu recentne strukturne i funkcionalne promjene šireg centra grada. Protagonistima nezavisne scene stoga se pristupilo iz perspektive aktera društvenih promjena u urbanom prostoru, koji svojim djelovanjem izravno utječu na društveno-kulturnu dinamiku grada. Seferagić (2007.) ističe da je urbane aktere moguće klasificirati na različite načine, no ujedno dodaje da se pri analizi njihovih uloga u promjenama u urbanom prostoru iznimno korisnom pokazuje tipologija koju predlaže Michel Bassand (2001.). Polazeći od teze kako su „upravo sukobi između aktera društvenih promjena ključni za razvoj grada“, Bassand (2007., prema Zlatar, 2013.:81) u urbanoj sredini detektira djelovanje najmanje četiriju tipova urbanih aktera koji imaju nejednak pristup resursima društva: ekonomske, političke, stručne i civilne aktere. ${ }^{2}$ Organizacije nezavisne kulturne scene u kontekstu ovog rada sagledavaju se kroz prizmu civilnih aktera, a njihovu borbu za prostorne resurse pritom se tumači kao borbu za ostvarivanje vlastitog prava na grad (Lefebvre, 1996.).

Razmatranje i upotreba koncepta prava na grad danas, više od pola stoljeća nakon što je Henri Lefebvre skovao tu formulaciju, ne predstavljaju nimalo jednostavan zadatak. Iako je tijekom proteklih dvaju desetljeća iznova dobio na važnosti u akademskim i aktivističkim krugovima, njegova upotreba i dalje je praćena prijeporima koji se tiču mobilizacijskog potencijala i stvarnog dosega tog koncepta (Brenner, Marcuse i Mayer, 2012.; Harvey, 2012.). Mayer (2012.) ističe da dodatne poteškoće proizlaze iz bitno različitih i često pojednostavljenih interpretacija Lefebvreove ideje, ali i njene institucionalne aproprijacije u svrhu legitimacije postojećih, tek rubno participativnih oblika upravljanja urbanim prostorom. U kontekstu ovog istraživanja, kao jedan od ključnih izazova nametnulo se pitanje operacionalizacije i empirijske upotrebljivosti Lefebvreovog koncepta. Na tom tragu, Marcuse (2012.:29) je mišljenja da pravo na grad predstavlja „samorazumljiv i intuitivno uvjerljiv slogan, ali i teorijski kompleksnu i provokativnu formulaciju“. Sam Lefebvre ne nudi razrađenu definiciju, ističući tek da se „pravo na grad navješćuje kao vapaj [i] kao zahtjev“ (Lefebvre, 2008.:28). U tom

2 Više o Bassandovoj tipologiji i njegovoj percepciji funkcioniranja urbane sredine vidjeti u: Zlatar (2013.). 
svjetlu, pokušaj operacionalizacije slijedio je liniju argumentacije koju razrađuje Peter Marcuse (2012.).

Analizirajući izdvojenu Lefebvreovu tvrdnju, Marcuse njene sastavne dijelove - vapaj i zahtjev - tumači kao zasebne aspekte ideje prava na grad te ih pritom terminološki prilagođava u svrhu preciznije analitičke razrade. $S$ jedne strane, radi se o neodložnim potrebama onog dijela populacije kojem su uskraćena temeljna ljudska prava i koji se bori kako bi zadovoljio osnovne egzistencijalne potrebe. $S$ druge strane, riječ je o aspiracijama onih koji - iako uspijevaju zadovoljiti spomenute potrebe - iskazuju nezadovoljstvo uvjetima života koji ograničavaju potencijale za razvoj i kreativnost. Sagledavanje prostorne problematike nezavisne kulturne scene u svjetlu ideje prava na grad i njegovog detaljnijeg tumačenja koje nudi Marcuse na prvi pogled nedvojbeno usmjerava ka potonjoj interpretaciji Lefebvreovog koncepta. No, s obzirom na gašenje brojnih inicijativa i projekata koji se nisu mogli nositi s neadekvatnim uvjetima djelovanja, borbu za prostore moguće je promotriti i kao svojevrstan vapaj za ispunjavanjem temeljnih egzistencijalnih potreba organizacija. Slogan „pravo na grad“ u ovom se kontekstu stoga odnosi na aspiraciju, ali i neodložno potraživanje aktera nezavisne kulturne scene, pri čemu obje interpretacije upućuju ka tvrdnji koju iznosi Mihoci (2015.:51) - „[pravo na grad je] pravo na korištenje grada kao poprišta borbe“.

Budući da je u fokusu ovog rada ponajprije borba organizacija za prostore djelovanja, valja istaknuti da se ideja prava na grad tumači prvenstveno kroz prizmu prava na prostor. Time se, međutim, ne iscrpljuju poveznice između Lefebvreovog koncepta i aktera nezavisne kulturne scene. Premda je Lefebvreov zahtjev uvriježeno tumačiti kao pravo pojedinca da ne bude ,izmješten“ u prostor proizveden specifično u svrhu diskriminacije (Schmid, 2012.), brojni autori ${ }^{3}$ naglašavaju da ta ideja podrazumijeva mnogo više od isključivog prava na pristup urbanim dijelovima grada i njihovo korištenje. Za Lefebvrea, riječ je o radikalno demokratskom momentu spoznaje prava na sudjelovanje u procesima proizvodnje grada i prostora, koja za sobom povlači čitav koloplet „popratnih“ prava kao što su pravo na različitost, pravo na informaciju te pravo na korištenje centra (Kofman i Lebas, 1996.). Upravo inzistiranje na spomenutim pravima, čije uskraćivanje, kao što će se pokazati, predstavlja temeljnu preokupaciju aktera nezavisne kulturne scene, ukazuje na opravdanost čitanja njihovih dugogodišnjih nastojanja u ključu borbe za ostvarivanje vlastitog prava na grad. ${ }^{4}$ Štoviše, doda li se tome i ,izrazito prisutna šira društvena osviještenost i orijentiranost na aktivizam“ (Višnić, 2008.:10), koja ih nerijetko krasi, moguće je tvrditi da organizacije

3 Primjerice, Harvey (2003.; 2012.), Mayer (2012.) te, u hrvatskim okvirima, Mihoci (2015.).

${ }^{4}$ Uz aktere nezavisne kulturne scene, sintagmu ,pravo na grad“ koristile su i udruge, organizacije i inicijative koje su sudjelovale u kampanji za Cvjetni trg i Varšavsku ulicu, koja je trajala od 2006. do 2011. godine, a iz čega je proizišla i udruga građana Pravo na grad. Više informacija na: https://pravonagrad.org/about// 
nezavisne kulturne scene u hrvatskim okvirima predstavljaju građanski angažirane urbane aktere koji svojim djelovanjem teže „,g]eneriranj[u] novih ideja i vrijednosti, razvijanj[u] participativnosti [i] poticanj[u] društvene i političke kritike" (Pepić i Tonković, 2018.:31). Naposljetku, upravo njihova fleksibilnost, otvorenost za suradnju i usmjerenost ka lokalnim sredinama navode na zaključak kako je riječ o „zasebnom polju koje [...] formira paralelni svijet koji je trajno obilježio hrvatsko društvo" (Vidović, 2007.:21).5

\section{Metodologija istraživanja}

Ovim istraživanjem težilo se steći uvid u značenja koja akteri nezavisne scene u Zadru pripisuju prostornim uvjetima vlastitog djelovanja, te je stoga implementiran kvalitativni pristup koji se pokazuje osobito prikladnim kada se želi doći do detaljnijeg razumijevanja fenomena od interesa (Creswell, 2007.). U tom nastojanju pokušalo se doći do odgovora na tri istraživačka pitanja: 1) kako akteri nezavisne kulturne scene u Zadru percipiraju ulogu prostora za djelovanje, 2) kako ocjenjuju postojeće javne politike i njihove reperkusije po vlastito polje djelovanja te 3) kako ocjenjuju utjecaj suvremenih procesa komercijalizacije i privatizacije prostora na dostupnost prostora za djelovanje.

Pritom je korištena tehnika polustrukturiranog intervjua, koja omogućuje zahvaćanje stavova i mišljenja sugovornika na kvalitativan, ali sustavan način (Denscombe, 2007.). Najveći dio intervjua proveden je u razdoblju od ožujka 2017. do travnja 2019. godine. Prikupljanje podataka odvijalo se do postizanja teorijskog zasićenja, pri čemu je na ukupno trajanje istraživanja utjecala i usmjerenost na osnivače ili voditelje ${ }^{6}$ organizacija, koji su često bili teže dostupni za provedbu intervjua, što je utjecalo na vremenski okvir istraživanja. Provedeno je devetnaest intervjua licem u lice s ukupno dvadeset i jednim sugovornikom, budući da su dva intervjua uključila po dvoje predstavnika pojedine organizacije ili inicijative na nezavisnoj kulturnoj sceni. Sve intervjue proveo je jedan od autora ovog rada, a sugovornici su prethodno bili obaviješteni o etičkim odredbama istraživanja i znanstvenog rada. ${ }^{7}$ Prosječna duljina trajanja intervjua iznosila je 75 minuta, a snimljeni razgovori transkribirani su uz pomoć programa Express Scribe.

${ }^{5}$ Za više pojedinosti o odrednicama ovog kulturnog polja vidjeti: Vidović (2007.; 2012.).

6 Gramatički rod u tekstu ne predstavlja rodnu oznaku te se izrazi koji imaju rodno značenje odnose jednako na muški i ženski rod.

${ }^{7}$ Istraživanje je provedeno u sklopu izrade diplomskog rada na Odjelu za sociologiju Sveučilišta u Zadru. Za potrebe diplomskog rada jedan od autora ovog istraživanja proveo je i dodatna dva intervjua s predstavnicima Grada Zadra koristeći poseban protokol. Zbog metodološke konzistentnosti istraživanja, s obzirom na ograničen broj predstavnika političkih aktera, ti intervjui nisu uključeni u analizu podataka na kojoj se temelji ovaj rad. 
Sudionici istraživanja odabrani su na temelju pripadnosti nekom od kolektiva nezavisne kulturne scene na području grada Zadra. Istraživačkom procesu prethodilo je „mapiranje" udruga, organizacija i inicijativa, kojim se težilo prepoznavanju aktera koji mogu ponuditi najkompleksniji uvid $\mathrm{u}$ iskustva pojedinog kolektiva te uvid u različita razdoblja djelovanja nezavisne kulturne scene. Kako bi se osiguralo što kompletnije zahvaćanje relevantnih aktera, uzorkovanje se odvijalo i metodom „snježne grude“, pri čemu su inicijalno mapirani sugovornici poslužili kao posrednici u detektiranju i kontaktiranju idućih sudionika istraživanja.

Budući da se istraživanjem težilo zahvatiti različita područja kulturno-umjetničkog i aktivističkog djelovanja poput plesa, glazbe, kazališta i književnosti, ono je uključilo bivše ili sadašnje predstavnike sljedećih udruga i umjetničkih organizacija, uključujući i one koje u trenutku prikupljanja podataka nisu bile aktivne: Zadarska vizija urbane kulture (Z.V.U.K.), Šigureca, Punktum, Zadarski plesni ansambl, Zalet, Zdanje, ZaPis, In Flux / U pokretu, Zadar snova, Eko-Zadar, Teatro VeRRdi, Dragon Teatar te Zajednica udruga Centar nezavisne kulture. Osim navedenih udruga i organizacija, u istraživanju su sudjelovali i predstavnici dvaju neformalnih društveno-kulturnih centara: Knjigozemska i Nigdjezemska. Od dvadeset jednog sugovornika, sedmero ih je primarno djelovalo u području stvaranja glazbe i/ili organizacije glazbeno-scenskih događaja, četvero u sferi suvremenog kazališta, po troje u sferi suvremenog plesa te u području ekologije i razvoja demokratske kulture, dok je jedan sugovornik bio aktivan u sferi književnosti. Područje djelovanja preostalih triju sugovornika zahvaćalo je različita područja kulturno-umjetničkog djelovanja, poput književnosti, audiovizualnih umjetnosti i glazbe (vidjeti Prilog 2). U istraživanju je sudjelovalo devet sugovornica i dvanaest sugovornika.

Protokol intervjua (vidjeti Prilog 1) sadržavao je pitanja koja je moguće podijeliti u četiri tematske cjeline. Prvi dio protokola odnosio se na opis djelovanja aktera nezavisne scene, prostorne uvjete u kojima se ono odvija te značenja koja sugovornici pripisuju polju nezavisne kulture. Drugi dio razgovora bio je usmjeren na ocjenu prostornih resursa grada Zadra i politike upravljanja njima te na ocjenu upotrebljivosti nekadašnjih i nadolazećih prostora nezavisne kulture. Trećim dijelom protokola nastojalo se zahvatiti ocjenu položaja nezavisne kulturne scene u kontekstu šireg civilnog društva, ali i njenog potencijala za preuzimanje istaknutije uloge na društveno-kulturnoj mapi grada. U konačnici, četvrti dio razgovora bio je usredotočen na percepciju položaja i uloga različitih tipova urbanih aktera te procjenu utjecaja procesa privatizacije i komercijalizacije javnih prostora na njihovu dostupnost.

Proces analize, odnosno kodiranja prikupljenih podataka odvijao se na trima razinama - deskriptivnoj, tematskoj i analitičkoj, pri čemu se nakon početnog utvrđivanja bazičnih kodova u idućim koracima analize težilo njihovom grupiranju u šire, zajedničke kategorije (Richards, 2015.). U svjetlu istraživačkih ciljeva, a imajući u vidu kon- 
ceptualni okvir kritičke urbane teorije, zaokružena analiza podataka iznjedrila je tri međusobno isprepletene teme: prostor kao upotrebni resurs, prostor kao tržišni resurs te uloga javnih politika (slika 1). Iskaze sugovornika nastojalo se sagledati polazeći od teze koju iznose Brenner, Marcuse i Mayer (2012.:3-4), a prema kojoj se „urbani prostor neprestano oblikuje i preoblikuje kroz neumoljivi sukob suprotstavljenih društvenih sila orijentiranih prema upotrebno i tržišno-vrijednosnim dimenzijama urbanih društveno-prostornih konfiguracija“. U konačnici, nužno je istaknuti osobnu i stručnu povezanost autora ovog rada s organizacijama nezavisne kulturne scene, zbog čega je istraživački proces uz epistemološku iziskivao i visoku razinu osobne refleksivnosti.

Slika 1.

Grafički prikaz analitičkih i tematskih kodova

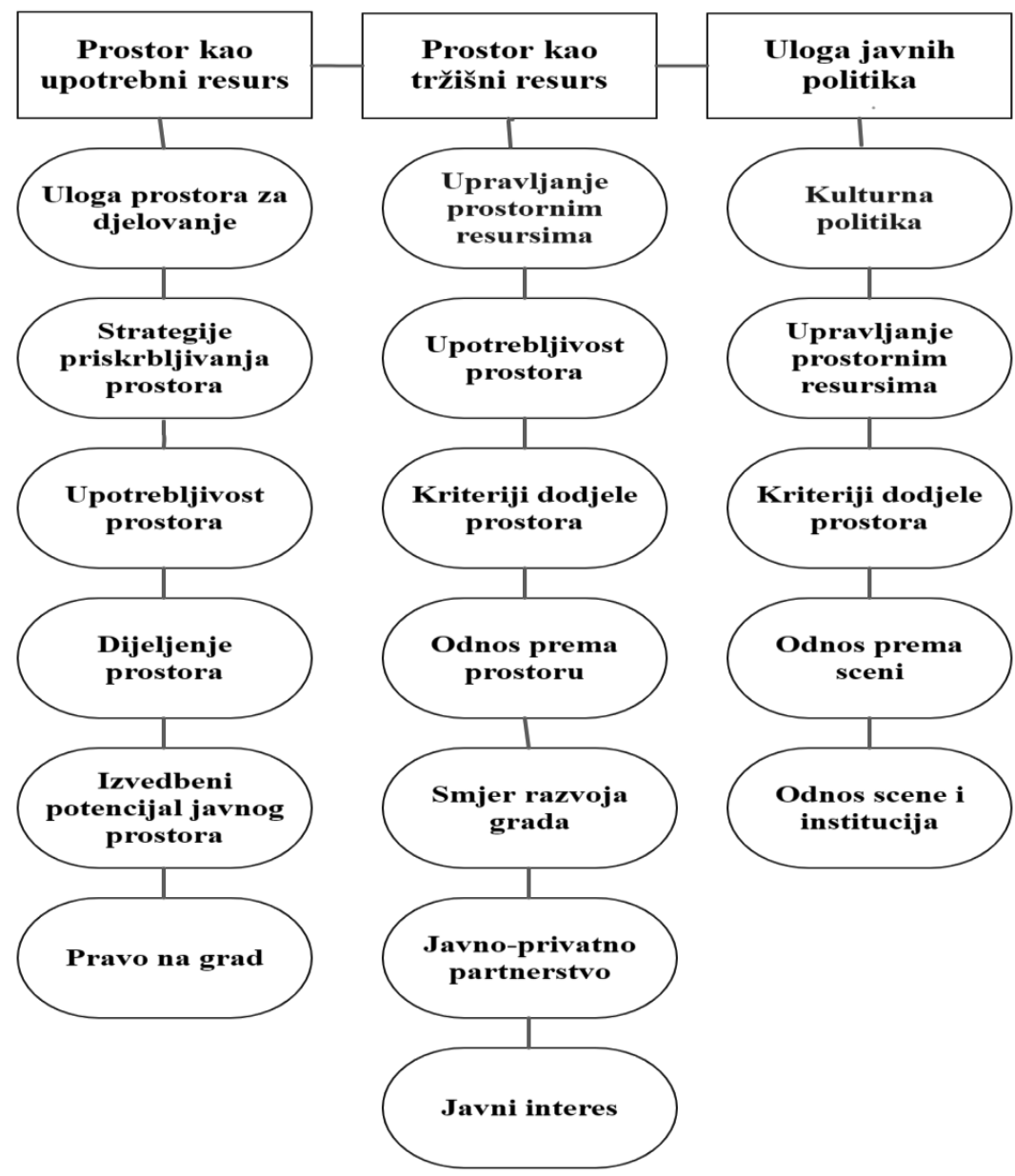




\section{Rezultati istraživanja}

Polazeći od nedostatka adekvatnih prostora za djelovanje organizacija nezavisne kulturne scene, težilo se stvaranju okvira koji bi omogućio dublje razumijevanje iskustava samih sugovornika, ali i procesa koji se nameću kao bitni čimbenici društveno-prostornog razvoja grada. Pritom je nužno istaknuti da je problem nedostatka prostora gotovo nemoguće odvojiti od ostalih poteškoća koje prate funkcioniranje nezavisne scene, pri čemu kao posebno problematične aspekte možemo izdvojiti nedovoljnu financijsku podršku te potkapacitiranost kolektiva članstvom. Prije no što se ponudi detaljnija razrada rezultata istraživanja, vrijedi naglasiti sljedeće: pojmu prostora se u kontekstu ovog rada pristupa ponajprije kroz prizmu zatvorenih fizičkih prostora. Iako (otvoreni) javni prostori poput trgova i parkova također predstavljaju iznimno vrijedne resurse, primarni fokus rada usmjeren je na nastojanja aktera scene da osiguraju adekvatne prostore za kontinuirano djelovanje.

U Strategiji razvoja nezavisnog kulturnog sektora grada Zadra iz 2013. godine Željka Tonković i Nenad Pepić kao gorući problem scene koji je prati od samih početaka ističu upravo nepostojanje adekvatnog prostora za djelovanje. Budući da detaljniji uvid u kronologiju borbi nezavisnih kulturnih aktera za prostor nadilazi okvire ovog rada, ovdje će se ukazati tek na pokušaje koji su svojom strukturiranošću i razinom organizacije bili najbliži omogućavanju prikladnijih uvjeta djelovanja za veći broj kolektiva. Kao najuspješniji projekt zadarske nezavisne scene pritom se izdvaja $A r t i k u l t u r a{ }^{8}$, koja se infrastrukturno temeljila na tripartitnoj suradnji javne uprave, civilnog i privatnog sektora. No, usprkos uspjehu koji se ocrtavao u velikom broju dobro posjećenih kulturnih programa u bivšem kinu Pobjeda, smještenom u samom centru grada, projekt posustaje nakon nepune dvije godine, budući da se prostor pokazao prezahtjevnim u pogledu troškova i održavanja. Vrijedi istaknuti i dva pokušaja okrupnjavanja scene pokretanje neformalne platforme Okret potpora 2013. te osnivanje Zajednice udruga Centar nezavisne kulture 2014. godine. I dok je Okret potpora bio zasnovan na šire postavljenom okviru zagovaračkih aktivnosti usmjerenih ka postizanju promjena u polju lokalne kulturne politike, osnivanjem Zajednice udruga primarno se težilo dugoročnijem rješavanju prostorne problematike. ${ }^{9} \mathrm{U}$ konačnici, oba pothvata pokazala su se neuspješnim u ostvarivanju zacrtanih ciljeva. Štoviše, gašenje aktivnosti Okreta potpora 2015. godine ujedno je označilo i početak višegodišnje stagnacije u nastojanjima da se nezavisna kulturna scena afirmira i nametne kao ravnopravan akter u kreiranju kulturne politike grada. Kao potencijalni agens promjene takvog stanja na-

\footnotetext{
8 Spomenuti projekt odvijao se u razdoblju od prosinca 2008. do lipnja 2010. godine.

9 Ovom se problemu pokušalo doskočiti prenamjenom zgrade bivšeg Kazališta lutaka Jazine (slika 2).
} 
zire se dugo očekivana izgradnja društveno-kulturnog centra ${ }^{10}$, kojim će se zadovoljiti dio infrastrukturnih potreba nezavisne kulturne scene. Međutim, kao što ističu Pepić i Tonković (2018.), znatnije promjene teško je očekivati bez radikalnog zaokreta u odnosu prema kulturi, praćenog konačnim prepoznavanjem i uvažavanjem nezavisne scene kao jednog od pokretača kulturne vitalnosti grada.

Slika 2.

Zgrada starog Kazališta lutaka Jazine

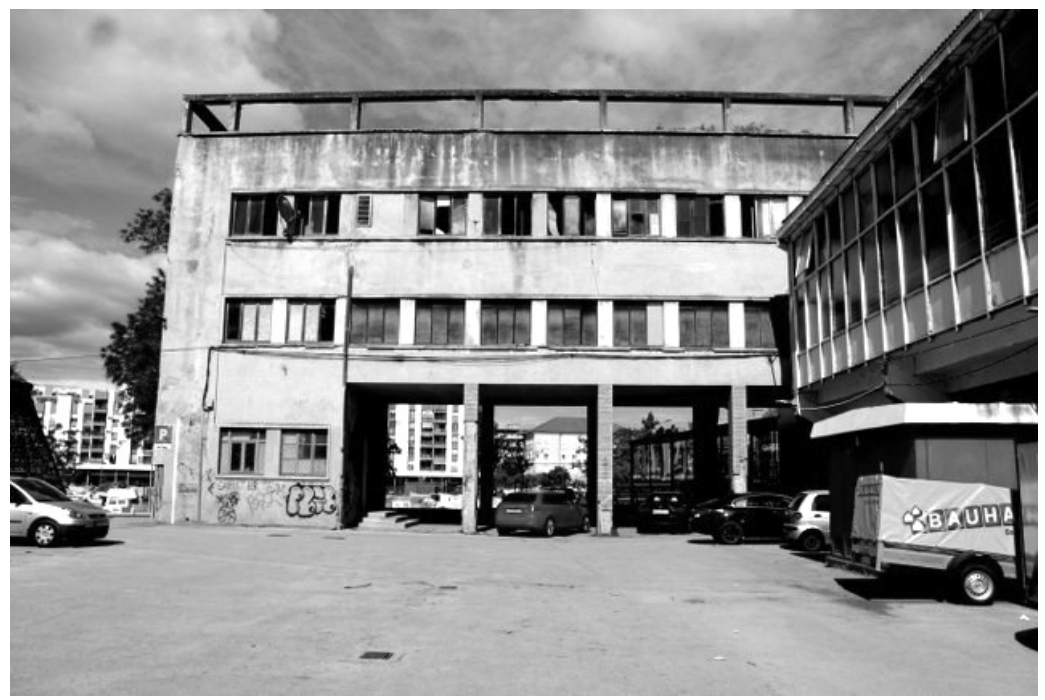

Izvor: Privatna arhiva autora rada

\subsection{Prostor kao upotrebni resurs}

Ukazujući na slabosti i snage zadarskog nezavisnog kulturnog sektora te prepoznajući nedostatak prostora kao njegov temeljni problem, Tonković i Pepić (2013.) kao jednu od ključnih strateških mjera razvoja ističu unapređenje postojećih i stvaranje novih prostornih i tehničkih uvjeta rada. Međutim, sudeći prema iskazima sugovornika, u godinama koje su uslijedile do takvih pomaka nije došlo, već su se, naprotiv, problemi

10 Nakon više od desetljeća najavljivanja, rekonstrukcija brownfield lokacije na kojoj će se nalaziti društveno-kulturni centar konačno je započela početkom veljače 2020. godine. Spomenuti objekt, smješten unutar kompleksa bivše vojarne, financira se bespovratnim sredstvima Europske unije. Kao što je istaknuto na mrežnim stranicama Grada Zadra, ,projektom se rekonstruira dvoetažni prostor površine $4500 \mathrm{~m}^{2}$ koji se nalazi pored postojeće [G]radske knjižnice[,] [a] [n]ovouređeni prostori prilagođeni su potrebama udruga mladih, nezavisne kulturne scene te građana koji su korisnici prostora knjižnice“. Preuzeto $s$ mrežnih stranica Grada Zadra: http://www.grad-zadar.hr/vijest/opce-vijesti-28/krece-izgradnja-centraza-mlade-5634.html [29.06.2020.]. 
dodatno produbili. Izuzev nekolicine udruga i inicijativa ${ }^{11}$, kolektivi nezavisne kulturne scene i dalje se suočavaju s nedostatkom (adekvatnog) prostora za pripremu i predstavljanje svog rada. Iako neki od njih, poput umjetničke organizacije Teatro VeRRdi ili udruge Zadarski plesni ansambl trenutno koriste prostore u vlasništvu Grada Zadra, oni su dostatni tek za skladištenje opreme, odnosno uvježbavanje izvedbi. Kada je u pitanju javna prezentacija rada, akteri se i dalje snalaze na različite načine, bilo da je riječ o sporadičnom korištenju prostora koji zahtijevaju prilagodbu ili o unajmljivanju nekog od institucionalnih prostora kulture kao što su Kazalište lutaka ili HNK Zadar. Možda upravo iz tog razloga - trajne nemogućnosti da osiguraju dugoročnije prostorno rješenje - akteri nezavisne scene gotovo su jednoglasni u ocjeni važnosti prostora za opstanak kolektiva:

Vlastiti prostor za djelovanje neke udruge, pogotovo u nezavisnoj kulturi, je osnova, bit i poanta svega. Znači, to je neka baza od koje se kreće, jer da bi scena mogla postojati, da bi scena nastala, [...] opstala $i$ da bi se razvijala, osnovno i najnužnije je prostor (S_07: 80-82).

Iz te, ali i brojnih drugih tvrdnji sugovornika vidljivo je da prostor predstavlja središnju preokupaciju aktera nezavisne scene, što umanjuje njihov kreativni i stvaralački potencijal. Baveći se uvjetima vlastitog djelovanja, akteri nezavisne kulturne scene prisiljeni su u drugi plan staviti njegovu stvarnu poantu - umjetničku produkciju. $\mathrm{Na}$ slične probleme ukazuje i Vidović (2010.:37), koja naglašava da je "dobar dio organizacija [...] okrenut tematiziranju uvjeta rada i borbi za popravljanje pozicija nezavisne kulture". Istovremeno, već spomenuto unajmljivanje scensko-izvedbenih prostora predstavlja dodatni financijski izdatak, što za posljedicu ima manjak financijskih resursa potrebnih za kulturno-umjetnički rad.

U svjetlu dugoročnog nedostatka adekvatnih prostora, akteri razvijaju različite strategije preživljavanja, koje uključuju unajmljivanje poslovnih ili institucionalnih prostora, korištenje prostorija drugih udruga i mjesnih odbora ${ }^{12}$, ali i samostalno zauzimanje, odnosno „skvotiranje“ napuštenih i nekorištenih građevina. Na tragu navedenog, rezultati istraživanja ukazuju na to da su organizacije nezavisne kulturne scene gotovo redovito bile primorane koristiti zapuštene i nefunkcionalne prostore za koje u datom razdoblju nije postojala namjena. No, čak i takvi prostori organizacijama su ustupani tek na privremeno korištenje, što je vidljivo i iz sljedeće tvrdnje:

11 Primjerice udruga Punktum, koja upravlja prostorom knjižnog kluba Knjigozemska, ili neformalna inicijativa Nigdjezemska, okupljena u istoimenom autonomnom kulturnom centru. Međutim, i ovdje valja istaknuti nesiguran karakter obaju prostora. Naime, ugovor o korištenju Knjigozemske vrijedi do 2022. godine, dok je u slučaju AKC Nigdjezemske riječ o skvotiranom prostoru.

12 Primjerice udruga Zadar snova, koja je u prostorije Mjesnog odbora Poluotok smjestila Društveni centar „ACME“, ili umjetnička organizacija Dragon Teatar, koja koristi prostor Mjesnog odbora Jazine II. 
Pa Grad je zasada [...] uglavnom dodjeljivao derutne [prostore]... dodjeljivao bi prostore koji više nisu mogli ispunjavati onu funkciju za koju su bili namijenjeni i s kojima nisu znali što bi u tom trenutku, do neke nove ideje svoje... ti su prostori uglavnom onda davani na određeni period sa tom nekakvom stavkom da će se možda prostor morati napustiti ranije, ukoliko se pokaže neka investicijska potreba od samog Grada... znači, nekakve prostore koji trenutno nisu imali nekakvu namjenu, ali su je planirali osmisliti za dalje, a nisu više zadovoljavali svoju funkciju i zapravo su to prostori koji čekaju nekog novog investitora... (S_06: 196-203)

Polazeći od zgrade stare Tehničke škole (2005.), preko bivšeg Kazališta lutaka (2011.) pa do kotlovnice nekadašnje vojarne „K1“ u ulici Stjepana Radića (2014.), koja je danas poznata kao Autonomni kulturni centar Nigdjezemska (slika 3), kolektivi zadarske scene u više su navrata ciljali na prostore u vlasništvu lokalne, regionalne ili državne uprave čije je ponovno stavljanje u funkciju iziskivalo znatnu količinu uložene energije i materijalnih sredstava. Dugo godina napušteni i derutni prostori prepoznati su kao potencijalno iskoristivi resursi, čiju su revitalizaciju kolektivi preuzimali na svoja leđa. No, takvi zahvati nerijetko su nadilazili ljudske i financijske kapacitete organizacija, te su bez ozbiljnije podrške vladajućih struktura gotovo u pravilu bili osuđeni na neuspjeh. Kao najeklatantniji primjer odnosa prema akterima nezavisne scene sugovornici ističu slučaj Kazališta lutaka Jazine, pri čemu se nespremnost vlasti na ozbiljniju suradnju manifestirala kroz nevoljkost ulaganja u prijeko potrebnu infrastrukturu i odbijanje uvjeta korištenja koje su predlagali predstavnici scene. Iako je Zajednica udruga tražila ustupanje prostora na razdoblje od pet godina, što bi omogućilo apliciranje na neke od natječaja iz europskih fondova u svrhu nasušno potrebne prostorne sanacije, Grad je ponudio trogodišnju opciju uz mogućnost ranijeg raskida ugovora. ${ }^{13} \mathrm{U}$ konačnici, ugovor za korištenje tog derutnog prostora nikad nije ni potpisan, a njegova sudbina zapečaćena je 2017. godine, kada je zgrada proglašena opasnom za korištenje i zaključana do daljnjeg. Za neke od organizacija, poput udruge Šigureca, koja je bila primarno usmjerena na organizaciju alternativnih glazbenih događaja, takav rasplet značio je gubitak jednog od rijetkih zatvorenih prostora u koje su mogli smjestiti svoje programe, što se posljedično odrazilo i na njihovu vitalnost. Riječima sugovornika:

[P]rostori padaju, Tehnička škola je pala, kino Pobjeda je pala, [...] staro Kazalište je palo... mislim, to je isto politika, nije oblik cenzure al je nemar [...] [P] ustili su da oni uđu tamo i osnovno što su oni - ili mi - tražili je bilo da se dobije ugovor na pet godina, da bi se moglo aplicirati na EU fondove, ali nisu htjeli to dat... i šta's sad... a nisu htjeli upucat nikakva sredstva, a trebalo je upucat bar jedno 200 'iljada kuna, da se sanira, ne znam, sanitarni čvor, stakla, prozori, ovo-ono, pa da to može nekako funkcionirat... (S_10: 183-191).

13 Kao što ističu Pelikan i Buljan (2014.:30), prostor Starog kazališta besplatno je posuđen Zajednici udruga Centar nezavisne kulture 2013. godine. Međutim, pritom valja istaknuti da je posudba dogovorena na rok od tri godine, uz opciju prijevremenog iseljenja „ukoliko Gradu prostor bude potreban“. 
Iz tvrdnji sugovornika moguće je zaključiti da su jedini objekti koji nude adekvatne uvjete rada ustvari institucionalni prostori kulture, čije upravljanje ocrtava balansiranje između njihove upotrebne i tržišne vrijednosti. Mnogi predstavnici organizacija nezavisne scene ističu upravo veću dostupnost tih prostora kao djelomično rješenje problema s kojima su suočeni. Međutim, sugovornici opetovano ukazuju na vlastitu ulogu „klijenta“ u prostorima poput Kazališta lutaka, HNK Zadar ili Kneževe palače, unatoč činjenici da nude sadržaj koji u potpunosti korespondira s profilom tih prostora. Nadalje, njihovo unajmljivanje u svrhu premijerne prezentacije rada ne odgovara na pitanje postprodukcijskog aspekta, budući da svako iduće uprizorenje podrazumijeva slične ili jednake troškove, što se izravno odražava na održivost programa.

Slika 3.

Autonomni kulturni centar Nigdjezemska

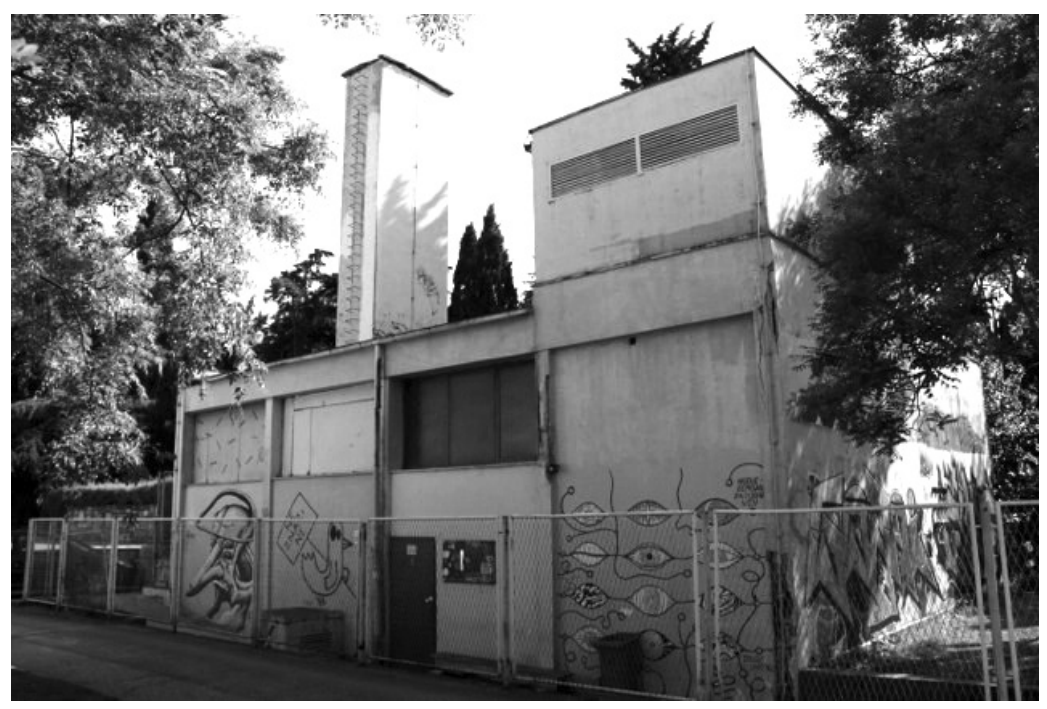

Izvor: Privatna arhiva autora rada

\subsection{Prostor kao tržišni resurs}

S obzirom na izniman broj prostora vojnog i industrijskog nasljeđa koji u Zadru još uvijek nisu privedeni nekoj drugoj funkciji te činjenicu da znatan broj udruga i organizacija i dalje ne posjeduje vlastiti prostor za djelovanje, ovim istraživanjem težilo se ponuditi potencijalno objašnjenje takvog stanja. U tom nastojanju nužno se vratiti odnosu prostornih aspiracija aktera scene i procesa koji uokviruju kontekst njihovog djelovanja. Sugovornici uviđaju izniman potencijal neiskorištene prostorne infrastrukture, ali i otkrivaju aspiracije koje su gotovo isključivo usmjerene na uži centar grada, bilo da je riječ o zatvorenim ili otvorenim javnim prostorima. Unatoč prepoznavanju pozitivnih aspekata decentralizacije kulturnih praksi, odnosno njihovog disperziranja 
u različite dijelove grada, Poluotok u očima kulturnih aktera i dalje zadržava svoju privlačnost. To naročito vrijedi za njegove otvorene javne prostore, koje je scena kroz godine koristila kako dragovoljno tako i iz puke nužnosti. No, kao što ističu sugovornici, ta mogućnost posljednjih godina ubrzano kopni zbog utjecaja turističke djelatnosti, koja se sve više nameće kao monokultura. ${ }^{14} \mathrm{U}$ bitci dvaju neravnopravnih suparnika, u kojoj ekonomija glavni resurs pronalazi u ljudima i prostoru, kultura sve teže drži korak i polako ostaje bez svog prava na korištenje centra:

Zadar je, kao i mnogi gradovi na moru, žrtva [...] bezočne eksploatacije prostora, jer kad si monokulturan u gospodarskom smislu, ništa ti drugo ne preostaje, jel... s obzirom da je pojeden prostor, tako da se svi prostori više manje stavljaju u funkciju turizma, šta onda tek [...] u nekom malom smislu i na kraju tog lanca dolazi do gradana, al uglavnom prostori funkcioniraju na način da odredenom dijelu ljudi donose profit $i$ to je sve... (S_08: 169-174).

Sugovornici u osvrtu na dinamiku prostornog razvoja detektiraju niz međusobno povezanih procesa koji se posljedično odražavaju i na njihove aspiracije, a koji bi se mogli podvesti pod zajednički nazivnik neodgovornog, nestručnog i netransparentnog gospodarenja (javnim) prostorom: dugogodišnje prepuštanje prostora devastaciji, privatizaciju i „umrtvljivanje“ javnih površina te eksploataciju prostora u turističke svrhe. Stupanj komercijalizacije povijesne jezgre grada možda se najbolje ogledava u tvrdnji jednog od sugovornika kako je na snazi „rat niskog intenziteta protiv [...] domicilnog stanovništva agresivnom komercijalizacijom [prostora]“, a u takvom odnosu snaga neprofitno djelovanje nezavisnog kulturnog sektora u doslovnom i prenesenom značenju teško pronalazi svoj prostor:

[N]ikad jedan skupi, vrijedni, komercijalno iskoristiv prostor ne ide za kulturu, uvijek ide za te komercijalne, skupe najmove... onda prostor, prije nego što se uredi, dok je još neka rupa, je li, Kazalište lutaka - [kao], davno smo ga mislili rušiti pa tamo graditi ne znam kakve marine i slično, onda u tom prostoru, dok smo mi kao Grad završili s korištenjem toga i još ga nismo spremni uredit, onda uleti kultura i koristi te nasušno potrebne kvadrate jer ih nema dovoljno... tako da, [...] svi prostori koji su sada kulturno zanimljivi su prostori samo zato što Grad još nije smislio drugu namjenu pa nije stigao srušit (S_12: 139-145).

Taj citat ukazuje na percepciju odnosa vladajućih struktura prema nezavisnoj kulturi, ali i široj sferi civilnog društva, te ujedno daje naslutiti i općenitiji problem odnosa prema prostoru. Štoviše, sugovornici smatraju da je prepuštanje brojnih neiskorištenih

${ }^{14}$ Kao primjer javnih prostora i površina koji posljednjih godina pod pritiskom komercijalnih djelatnosti tijekom ljetne sezone postaju nedostupni moguće je navesti Forum i Trg pet bunara. Osim tih primjera, pojedini javni prostori koje su koristile organizacije nezavisne kulturne scene posljednjih se godina koriste ili se namjeravaju prenamijeniti za potrebe institucionalne kulture, većinom reprezentativnog karaktera (primjerice Kapetanski park, crkva sv. Nikole i dvorište Providurove palače). 
prostora utjecaju vremena moguće sagledati u svjetlu njihovog „čuvanja“ do nekih povoljnijih investicijskih prilika, pri čemu ističu bitno različite percepcije postojećih procesa upravljanja prostornim resursima. Prema njihovom mišljenju, ono što civilni akteri percipiraju kao neodgovoran odnos prema (javnom) prostoru koji posjeduje svoju upotrebnu vrijednost, politički i ekonomski akteri prihvaćaju kao podnošljiv gubitak u kontekstu budućih ulaganja i profita koji će ona generirati. Sugovornici naglašavaju da zemljišta i nekretnine nerijetko predstavljaju i sredstva razmjene u doslovnom smislu, koja se u odnosima različitih razina javne uprave pokazuju kao važni aduti u ostvarivanju strateških ciljeva. Atraktivnost lokacije i tržišna vrijednost prostora nameću se kao prepreka korištenju građevina čiji fizički okoliš iščekuje nove investitore ili povoljniji trenutak za realizaciju već postojećih urbanističkih planova.

\subsection{Uloga javnih politika}

U osvrtu na politike prostornog upravljanja sugovornici prepoznaju niz problema, koji se kreću u rasponu od dugotrajnosti procesa revidiranja gradske imovine i nedostupnosti informacija o njoj, preko diskutabilnih kriterija i izostanka formalnih mehanizama dodjeljivanja prostornih resursa pa sve do zapuštenosti javnih prostora $\mathrm{i}$ izostanka kontrole pridržavanja uvjeta njihovog korištenja. U svjetlu tumačenja javnih politika kao odgovora političkih elita na zahtjeve građana za određenim javnim dobrima, vrijedi istaknuti da sugovornici procese kojima svjedoče ne prepoznaju kao sustavno i plansko djelovanje usmjereno ka stvarnim potrebama lokalne zajednice:

Pa mislim da Grad uopće nema ikakvu politiku [upravljanja prostorima], nego da se to sve dogada stihijski... dakle, ono, u nekom trenutku, ako nešto, negdje, onda će oni tako postupiti, al dugoročnu strategiju oni nemaju niti su ikad imali, jer to se vidi iz dosadašnjih rezultata, na koji su način rukovodili prostorima i kako su ih dodjeljivali, kome i po kojim kriterijima, tako da, ono, apsolutno ne postoji nikakva konkretna politika što se tiče prostora Grada, barem je to moje mišljenje... (S_07: 73-77).

Unatoč postojanju strateških dokumenata prostorne politike i urbanog razvoja ${ }^{15}$, akteri nezavisne scene smatraju da se gradskom imovinom i objektima ne upravlja sustavno, već stihijski, kako bi se zadovoljili parcijalni interesi. Osim toga, sudionici istraživanja u nekoliko su navrata spomenuli i nepostojanje kulturne strategije grada. Međutim, treba napomenuti kako su izrada i usvajanje tog dokumenta (Plan razvoja kulture grada Zadra 2019. - 2026., Jelinčić i Tišma, 2020.) uslijedili nakon prikupljanja podataka za potrebe ovog istraživanja.

15 Riječ je o sljedećim dokumentima: Strategija razvoja grada Zadra 2013. - 2020. (dostupno na: https:// www.grad-zadar.hr/repos/doc/Strategija\%20razvoja\%20grada\%20Zadra.pdf) i Strategija razvoja urbanog područja Zadra 2014. - 2020. (dostupno na: https://www.grad-zadar.hr/repos/doc/Strategija\%20 razvoja\%20urbanog\%20podrucja\%20Zadra\%202014.\%20-\%202020..pdf). 
Iako su sugovornici veoma oštri u ocjenjivanju različitih praktičnih aspekata gospodarenja prostorom, stječe se dojam da najviše nezadovoljstva proizlazi iz ograničenog pristupa informacijama, kako o prostorima u vlasništvu Grada tako i o planiranim prostornim zahvatima. U iščekivanju najavljenog, ali sporog procesa revidiranja gradske imovine, potencijalnim korisnicima preostaju alternativni načini informiranja o dostupnosti određenih prostora. Netransparentnost djelovanja javne uprave očituje se i kroz nedostatak jasnih kriterija i uvjeta za dodjeljivanje prostora na korištenje, što otvara prostor za razne špekulacije i ostavlja dojam dodjeljivanja prostora na temelju nekog vida podobnosti. Takva percepcija dodatno narušava ionako nisku razinu povjerenja u institucije, koje, po mišljenju sugovornika, svoj posao ne obavljaju na za to primjeren i dovoljno transparentan način. Riječima sugovornika:

Mislim da prvenstveno nisu jasni kriteriji, to je ono najosnovnije... evo, sad prvi put zapravo čujemo da će se objaviti nekakav natječaj, i on je formuliran prema kriterijima koji su zapravo prepisani od nekakve nacionalne strategije i [...] doneseni na nekakvoj nacionalnoj razini, medutim, koji kvalitativno ne odgovaraju na odredena pitanja [...] [K] riteriji dosada apsolutno nisu bili jasni i zapravo ne znamo na koji su se način dodjeljivali prostori, ja nikad nisam ni vidjela natječaj za dodjeljivanje prostora za udruge... (S_06: 249-256).

Uz politike prostornog upravljanja, rezultati istraživanja ukazuju na nezanemarivu ulogu institucionalnog okvira lokalne kulturne politike, koji sugovornici ističu kao važan čimbenik nezadovoljavajućeg stanja cjelokupnog kulturnog sektora grada. Već spomenuto dugogodišnje nepostojanje kulturne strategije sugovornici prepoznaju kao pokazatelj nedostatka jasne vizije kulturnog razvoja, kojem se u takvim okolnostima pristupalo prvenstveno kroz održavanje već uhodanog načina djelovanja kulturnih ustanova. Na tom tragu, iskazi sugovornika govore u prilog tezi da „kulturni sustav u Hrvatskoj nije uspio prevladati prepreku tzv. ‘staklenog stropa) u kulturnom razvoju, koji označava ograničeni prostor za uspostavu ravnoteže u razvoju institucionalnoga u odnosu na izvaninstitucionalni kulturni sektor" (Vidović, Mišković i Žuvela, 2018.:57). Takvu tvrdnju moguće je potkrijepiti i sljedećim iskazom jednog od sugovornika:

[T]u nije bilo stvarne volje politike koja je imala jedan čudan odnos prema toj sceni, a to je da je nikad nisu mogli to pojmiti kao [...] normalan dio kulturne scene... oni su mogli pojmiti da je neki KUD kultura, mogli su pojmiti da je klapa kultura, ali da je alternativno kazalisste ili nekakav glazbeni sastav kultura, to njima nikako nije dolazilo u glavu... (S_08: 46-50).

Kao i u slučaju ocjene politika prostornog upravljanja, sugovornici iznose čitav niz kritika, koje uključuju inertnost i nestručnost kulturne administracije, dodjeljivanje financijskih sredstava po principu inercije ili podobnosti te nedovoljan broj kulturnih 
vijeća. ${ }^{16} \mathrm{U}$ svjetlu brojnih primjera u kojima gradske strukture nisu pokazale sluha za potrebe nezavisnog sektora, akteri scene opetovano ukazuju na nepovratno narušeno povjerenje, koje stoji na putu kvalitetnijoj komunikaciji i suradnji.

U takvoj konstelaciji, pomalo neočekivani izazov za scenu predstavlja suočavanje $s$ vizijom promjene koja se nameće „odozgo“, a koja se manifestira u obliku dugo očekivanog početka izgradnje društveno-kulturnog centra rekonstrukcijom zapuštenog objekta u sklopu nekadašnje vojarne (slika 4). Pri spomenu suradnje nezavisnog sektora i javne uprave valja istaknuti da bi ona u slučaju budućeg centra trebala dobiti novu dimenziju. Naime, upravljanje društveno-kulturnim centrom trebalo bi funkcionirati po principima javno-civilnog partnerstva, ili, preciznije, jednog od modela sudioničkog upravljanja u kulturi. S obzirom na izostanak uzajamnog povjerenja i nezadovoljavajuću komunikaciju kulturnih i političkih aktera, za zaključiti je da će planirani ustroj centra za obje strane predstavljati značajan test njihovih kapaciteta.

Slika 4.

Gradilište budućeg društveno-kulturnog centra

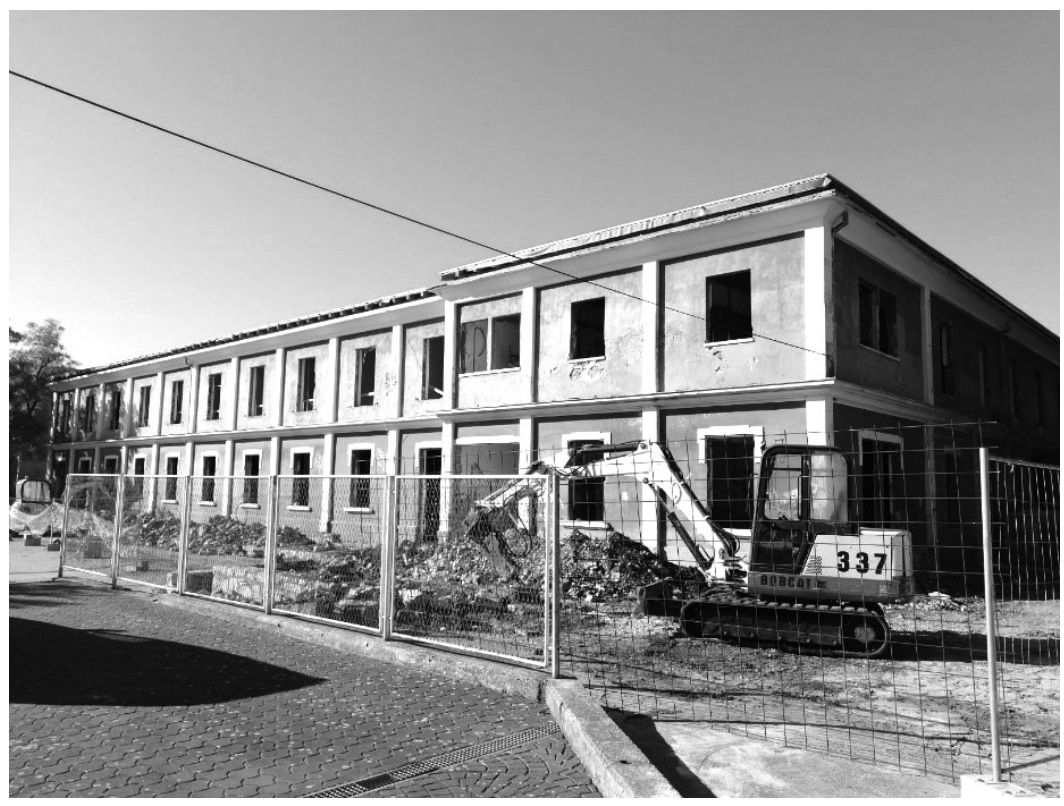

Izvor: Privatna arhiva autora rada

16 Za razliku od gradova poput Pule, koja broji šest, te Rijeke, sa čak sedam kulturnih vijeća, u Zadru je osnovano tek jedno kulturno vijeće koje nastoji pokriti veoma široki raspon kulturnih djelatnosti. 


\section{Zaključna razmatranja}

Slijedeći motrište prema kojem „nezavisna kulturna scena predstavlja bitan pokretač kulturne vitalnosti gradova" (Tonković i Pepić, 2013.:19), ovim radom pokušalo se ponuditi uvid u temu koju je moguće percipirati kao specifikum zadarske nezavisne kulture - borbu njenih aktera za priskrbljivanje adekvatnih prostora za djelovanje. Premda je nedostatak prostora za djelovanje prepoznat kao jedan od ključnih problema nezavisne kulturne scene, prethodna istraživanja i publikacije nisu ga detaljnije zahvatile niti ga pokušale smjestiti u širi kontekst odnosa moći među različitim akterima urbanih promjena. Kako bi se spomenuti problem sagledao iz perspektive aktera nezavisne kulturne scene, provedeno je kvalitativno istraživanje. U teorijskom smislu rad je svoje uporište pronašao u tradiciji kritičke urbane teorije i djelovanju autora poput Henrija Lefebvrea i Michela Bassanda. Povezujući Lefebvreovu ideju prava na grad s Bassandovom tipologijom urbanih aktera, odnos prema nezavisnoj kulturnoj sceni pokušao se sagledati kao svojevrstan indikator odnosa prema (javnom) prostoru i široj lokalnoj zajednici. Polazeći od kritike kapitalističke proizvodnje urbanog prostora i upravljanja njime, koja leži u osnovi kritičke urbane teorije, odnosu prema prostornim resursima pristupilo se kroz prizmu dihotomije njihove upotrebne i tržišne vrijednosti, smatrajući da upravo potonji aspekt može poslužiti u svrhu razumijevanja društvenog konteksta koji uokviruje djelovanje nezavisne kulturne scene.

Rezultati istraživanja sugeriraju da upotrebna vrijednost prostora sve više gubi na važnosti, što naročito vrijedi za zadarsku staru gradsku jezgru, poznatiju kao Poluotok. Unatoč postojanju znatnog broja nekadašnjih vojnih i industrijskih objekata koji u širem centru grada još uvijek nisu privedeni novoj funkciji, projekcija njihove tržišne vrijednosti često se nameće kao čimbenik njihove nedostupnosti različitim potencijalnim korisnicima iz sfere civilnog društva. Slično vrijedi i za otvorene javne prostore, koji su izloženi sve izraženijim procesima komercijalizacije i privatizacije. U svjetlu prevladavajuće orijentiranosti na turizam, koji se profilira kao gospodarska monokultura, kolektivi nezavisne kulturne scene suočavaju se i s nestankom alternativnih prostornih rješenja u formi javnih prostora i površina. $\mathrm{Na}$ taj način nezavisna scena ostaje bez svog prava na koristenje centra grada, koji se ubrzano pretvara u turističku kulisu koja značajniju dinamiku korištenja bilježi isključivo tijekom ljetne sezone. Strategije preživljavanja koje scena pritom koristi nose teret (trajne) privremenosti i nemogućnosti dugoročnijeg planiranja i promišljanja vlastitog djelovanja. Štoviše, rezultati sugeriraju da su dugotrajna i iscrpljujuća borba za prostor i neprikladni uvjeti djelovanja za neke od organizacija predstavljali nepremostivu prepreku, koja je na koncu pridonijela odluci o gašenju udruge ili inicijative.

Rezultati također sugeriraju nezanemarivu ulogu dviju sfera javnih politika - kulturnog i prostornog planiranja. U kontekstu teorijsko-konceptualnog okvira rada, promišljanje tih aspekata analizu je usmjerilo prema osporavanju prava na različitost i prava na informaciju o kojima govori Lefebvre. Prema mišljenju sugovornika, nezavi- 
sna scena izložena je rastućim pritiscima dominantnih obrazaca tržišnih nadmetanja, koji proizlaze prvenstveno iz konstantnog nerazumijevanja i neprihvaćanja njenih temeljnih odrednica. Istraživanje ukazuje na kronični nedostatak političke volje da se akteri nezavisne scene prepoznaju i vrednuju kao stvarna kulturna vrijednost grada, „koja nastaje kao proizvod sadašnjeg vremena, pritom stvarajući nove vrijednosti i odrednice identiteta" (Tonković i Pepić, 2013.:3). Doda li se tome i ograničeni pristup informacijama o ključnim elementima upravljanja prostorima, moguće je pretpostaviti da javne politike ne uspijevaju opravdati svoj atribut i uistinu se postaviti u službu građana. Međutim, za donošenje takvog zaključka bilo bi uputno provesti opsežnije istraživanje koje bi obuhvatilo i druge tipove urbanih aktera, ali i ostale aspekte prostornog planiranja.

U svjetlu nalaza istraživanja, nadolazeći projekt rekonstrukcije društveno-kulturnog centra trebao bi ponuditi djelomično rješenje prostornih potreba scene, ali i testirati spremnost lokalne kulturne politike na iskorak u odnosu spram zadarske nezavisne kulture. Iako su akteri scene za vrijeme trajanja ovog istraživanja iznosili mahom negativne stavove o tom objektu, smatrajući da njegova izgradnja neće rezultirati bitnim pomacima polja kojem pripadaju, naknadni razvoj događaja ukazao je na spremnost dijela aktera na ozbiljnije uključivanje u cjelokupni projekt. S obzirom na to da bi spomenuti centar trebao funkcionirati po principima javno-civilnog partnerstva, razdoblje koje slijedi predstavljat će izniman test kapaciteta civilnih, ali i političkih aktera. Dovršenje tog projekta, predviđeno za lipanj 2021. godine, nedvojbeno će izmijeniti dosadašnje uvjete djelovanja aktera nezavisne kulturne scene, nudeći im prijeko potrebne prostorne resurse. Imajući na umu Bassandovu tvrdnju prema kojoj utjecaj pojedinih aktera na promjene u urbanom prostoru u pravilu ovisi o moći i resursima kojima raspolažu (Svirčić Gotovac, 2009.), novonastale okolnosti otvorit će prostor za ozbiljnije pozicioniranje nezavisne scene na društveno-kulturnoj mapi grada. No, iako nalazi ovog istraživanja govore u prilog tezi o gotovo presudnoj ulozi prostornih resursa u aktiviranju potencijala nezavisne kulturne scene, tek će vrijeme pokazati jesu li autori pri donošenju takvog zaključka bili u pravu.

\section{Literatura}

1. Barada, V.; Primorac, J. i Buršić, E. (2016). Osvajanje prostora rada. Uvjeti rada organizacija civilnog društva na području suvremene kulture i umjetnosti. Zagreb: Biblioteka Kultura nova.

2. Brenner, N. (2017). Critique of Urbanization: Selected Essays. Basel: Birkhäuser Verlag GmbH.

3. Brenner, N.; Marcuse, P. and Mayer, M. (2012). Cities for people, not for profit: an introduction, in: Brenner, N.; Marcuse, P. and Mayer, M. (Eds.). Cities for people, not for profit: critical urban theory and the right to the city. London and New York: Routledge, 1-10. 
4. Creswell, J. W. (2007). Qualitative inquiry and research design. Choosing among five approaches. Thousand Oaks, London, New Delhi: Sage Publications.

5. Denscombe, M. (2007). The Good Research Guide (for small-scale social research projects). Buckingham: OUP.

6. Harvey, D. (2003). The Right to the City. International Journal of Urban and Regional Research, 27 (4): 939-941.

7. Harvey, D. (2012). Rebel Cities. From the Right to the City to the Urban Revolution. London and New York: Verso.

8. Jelinčić, D. i Tišma, S. (2020). Plan razvoja kulture grada Zadra 2019.-2026. Zagreb: Institut za razvoj i međunarodne odnose - IRMO.

9. Kofman, E. and Lebas, E. (Eds.) (1996). Writings on Cities. Henri Lefebure. Oxford and Malden: Blackwell Publishers Ltd.

10. Lefebvre, H. (1996). Right to the City, in: Kofman, E. and Lebas, E. (Eds.). Writings on Cities. Henri Lefebvre. Oxford and Malden: Blackwell Publishers Ltd, 63-177.

11. Lefebvre, H. (2008). Pravo na grad, u: Kovačević, L.; Medak, T.; Milat, P.; Sančanin, M.; Valentić, T.; Vuković, V. (Ur.). Operacija: Grad. Priručnik za život u neoliberalnoj stvarnosti. Zagreb: Savez za centar za nezavisnu kulturu i mlade, Multimedijalni institut, Platforma 9,81 - Institut za istraživanja u arhitekturi, BLOK - Lokalna baza za osvježavanje kulture, SU Klubtura/Clubture, 16-29.

12. Marcuse, P. (2012). Whose right(s) to what city?, in: Brenner, N.; Marcuse, P. and Mayer, M. (Eds.). Cities for people, not for profit: critical urban theory and the right to the city. London and New York: Routledge, 24-41.

13. Mayer, M. (2012). The right to the city in urban social movements, in: Brenner, N.; Marcuse, P. and Mayer, M. (Eds.). Cities for people, not for profit: critical urban theory and the right to the city. London and New York: Routledge, 63-85.

14. Mihoci, N. (2015). Pravo na grad. Kritička misao o urbanom prostoru. Diplomski rad. Zagreb: Filozofski fakultet Sveučilišta u Zagrebu.

15. Mrakovčić, M. (2015). Prostori nezavisne kulture u Hrvatskoj. MANEK: magazin nezavisne kulture, 4: 72-79.

16. Pelikan, J. i Buljan, I. (2014). Strategija razvoja Zajednice udruga „Centar nezavisne kulture" 2014. - 2018. Zadar: Udruga Eko-Zadar.

17. Pepić, N. i Tonković, Ž. (2018). Misli o nezavisnoj sceni grada Zadra, u: Sodar S. (Ur.). MONOgrafija. Zadar: Monoplay - festival suvremenog plesa, 30-31.

18. Primorac, J. (2008). Razvoj kulturnih/kreativnih industrija u Hrvatskoj - perspektiva kulturnih djelatnika, u: Švob-Đokić, N.; Primorac, J. i Jurlin, K. (Ur.). Kultura zaborava. Industrijalizacija kulturnih djelatnosti. Zagreb: Naklada Jesenski i Turk, Hrvatsko sociološko društvo, 69-117.

19. Richards, L. (2015). Handling Qualitative Data: A Practical Guide. Los Angeles/ London/New York/New Delhi/Singapore: SAGE Publications.

20. Schmid, C. (2012). Henri Lefebvre, the right to the city, and the new metropolitan mainstream, in: Brenner, N.; Marcuse, P. and Mayer, M. (Eds.). Cities for people, not for profit: critical urban theory and the right to the city. London $\mathrm{i}$ New York: Routledge, 42-62. 
21. Seferagić, D. (2007). Akteri društvenih promjena u urbanom prostoru Hrvatske. Sociologija i prostor, 45 (3-4): 361-376.

22. Svirčić Gotovac, A. (2009). Utjecaj društvenih aktera na procese gentrifikacije i pauperizacije: primjer Zagreba. Doktorska disertacija. Zagreb: Filozofski fakultet Sveučilišsta u Zagrebu.

23. Šakaja, L. (1999). Kultura i prostor. Prostorna organizacija kulturnih djelatnosti u Hrvatskoj. Zagreb: Hrvatska sveučilišna naklada.

24. Tonković, Ž. (2012). Društvene mreže aktera u kulturnom i kreativnom sektoru kao pokazatelj razvojnih potencijala - primjer grada Zadra. Doktorska disertacija. Zagreb: Filozofski fakultet Sveučilišta u Zagrebu.

25. Tonković, Ž. i Pepić, N. (2013). Strategija razvoja nezavisnog kulturnog sektora grada Zadra.

26. Tonković, Ž.; Marcelić, S. i Krolo, K. (2017). Kulturna potrošnja, društvene nejednakosti i regionalne razlike: istraživanje Eurobarometra u Hrvatskoj 2013. godine. Sociologija i prostor, 55 (2): 187-208.

27. Tonković, Ž. and Sekelj, S. (2018). Duality of Structure and Culture: A Network Perspective on the Independent Cultural Scene in Zagreb and the Formation of the WHW Curatorial Collective, in: Kolešnik, Lj. and Horvatinčić, S. (Eds.). Modern and Contemporary Artists' Networks. An Inquiry into Digital History of Art and Architecture. Zagreb: Institut za povijest umjetnosti, 166-192.

28. Vidović, D. (2007). Razvoj hrvatske nezavisne kulturne scene (1990.-2002.) ili što sve prethodi mreži Clubture, u: Vidović, D. (Ur.). Clubture. Kultura kao proces razmjene 2002.-2007. Zagreb: Savez udruga Klubtura/Clubture.

29. Vidović, D. (2010). Nezavisna kultura u Hrvatskoj (1990-2010), u: Mrduljaš, M. i Vidović, D. (Ur.). Dizajn i nezavisna kultura. Zagreb: Savez udruga Klubtura/Clubture, 8-40.

30. Vidović, D. (2012). Razvoj novonastajucih kultura u gradu Zagrebu od 1990. do 2010. Doktorska disertacija. Zagreb: Filozofski fakultet Sveučilišta u Zagrebu.

31. Vidović, D.; Žuvela, A. i Mišković, D. (2018). Sudioničko upravljanje u kulturi u Republici Hrvatskoj, u: Vidović, D. (Ur.). Uradimo zajedno. Prakse i tendencije sudioničkoga upravljanja u kulturi u Republici Hrvatskoj. Zagreb: Biblioteka Kultura nova, 44-95.

32. Višnić, E. (2008). Kulturne politike odozdo. Nezavisna kultura i nove suradničke prakse u Hrvatskoj. Zagreb: Policies for Culture.

33. Zlatar, J. (2013). Urbane transformacije suvremenog Zagreba. Sociološka analiza. Zagreb: Plejada/Institut za društvena istraživanja u Zagrebu. 


\section{Prilozi}

\section{Protokol intervjua}

1. Kako biste opisali svoje djelovanje na zadarskoj nezavisnoj kulturnoj sceni?

2. Što za Vas predstavlja nezavisna kulturna scena?

3. Posjeduje li organizacija kojoj pripadate vlastiti prostor za djelovanje?

Ako da: Na koji ste način uspjeli osigurati vlastiti prostor? Kako se priskrbljivanje prostora odrazilo na djelovanje Vaše organizacije? Zadovoljava li potrebe Vaše organizacije?

Ako ne: Na koje načine pokušavate doći do alternativnih prostora za održavanje programa? Kako se nedostatak prostora odražava na djelovanje organizacije? Što za Vas uopće znači vlastiti prostor?

4. Kako ocjenjujete prostorne resurse grada Zadra? Smatrate li da u Zadru postoje prostori koji bi odgovarali potrebama većeg dijela organizacija nezavisne kulturne scene?

5. Kako biste ocijenili upotrebljivost i prikladnost prostora koje je nezavisna kulturna scena koristila kroz godine?

6. Po Vašem mišljenju, što bi izgradnja Centra za mlade mogla značiti za nezavisnu kulturnu scenu? S obzirom na raznolikost organizacija koje tvore zadarsku nezavisnu scenu, kako vidite mogućnost djelovanja u zajedničkom prostoru?

7. Koje je Vaše viđenje politike upravljanja prostorima kojima Grad raspolaže? Prema kojim kriterijima lokalne vlasti donose odluke o dodjeljivanju prostora? U kojoj se mjeri pri upravljanju prostornim resursima vodi računa o javnom interesu?

8. S obzirom na pripadajuću moć i utjecaj, kako biste ocijenili hijerarhiju pojedinih tipova aktera (ekonomski, stručni, politički, civilni) na društvenoj mapi grada Zadra? Kako vidite doprinos tih tipova aktera razvoju grada? Što za pojedine tipove aktera predstavlja ideja razvoja grada?

9. Kako vidite položaj organizacija nezavisne kulturne scene u odnosu na neke druge civilne udruge grada Zadra (primjerice, braniteljske, sportske...)? Kako to tumačite?

10. Posjeduje li nezavisni kulturni sektor potencijal da se nametne kao važan akter na zadarskoj društveno-kulturnoj sceni? U čemu se ogleda taj potencijal? Koju ulogu u kontekstu aktiviranja tih potencijala ima posjedovanje adekvatnog prostora za djelovanje?

11. Što za Vas predstavlja ideja „prava na grad“? Kako vidite tu ideju u kontekstu djelovanja nezavisne kulturne scene?

12. Kako ocjenjujete izvedbeni potencijal zadarskih javnih prostora? Možete li dati neki vlastiti primjer korištenja javnog prostora u kulturno-umjetničke svrhe?

13. U posljednje vrijeme se govori o izraženijoj privatizaciji i komercijalizaciji javnih prostora. Vidite li slične procese na djelu i u Zadru? Kakvo je Vaše viđenje „,javnoprivatnog partnerstva“? 


\section{Popis sugovornika}

\begin{tabular}{|c|c|c|}
\hline $\begin{array}{c}\text { Sugovornik/ca } \\
\text { (šifra) }\end{array}$ & Vrsta organizacije & Područje djelovanja \\
\hline S_01 & neformalna inicijativa & glazba/aktivizam \\
\hline S_02 & neformalna inicijativa & glazba/aktivizam \\
\hline S_03 & udruga & glazba/aktivizam \\
\hline S_04 & udruga & glazba \\
\hline S_05 & udruga & književnost/glazba/ vizualne umjetnosti \\
\hline S_06 & udruga & književnost/glazba/ vizualne umjetnosti \\
\hline S_07 & udruga & glazba/književnost \\
\hline S_08 & umjetnička organizacija & scensko-izvedbene umjetnosti/glazba \\
\hline S_09 & udruga & suvremeni ples \\
\hline S_10 & umjetnička organizacija & scensko-izvedbene umjetnosti/glazba \\
\hline S_11 & udruga & glazba/urbana kultura \\
\hline S_12 & udruga & suvremeni ples \\
\hline S_13 & udruga & književnost \\
\hline S_14 & neformalna inicijativa & glazba/aktivizam \\
\hline S_15 & udruga & suvremeni ples/urbana kultura \\
\hline S_16 & udruga & scensko-izvedbene umjetnosti \\
\hline S_17 & umjetnička organizacija & scensko-izvedbene umjetnosti \\
\hline S_18 & udruga & interdisciplinarno područje \\
\hline S_19 & udruga & ekologija/demokratska kultura/aktivizam \\
\hline S_20 & udruga & ekologija/demokratska kultura/aktivizam \\
\hline S_21 & udruga & ekologija/demokratska kultura/aktivizam \\
\hline
\end{tabular}


Izvorni znanstveni rad

\title{
Independent Cultural Scene as an Actor of Changes in Urban Space: The Example of Zadar
}

\author{
Željka Tonković \\ Univesity of Zadar, Department of Sociology, Croatia \\ e-mail:zeljka.tonkovic@unizd.hr \\ Hrvoje Pašalić \\ e-mail:hrvoje.pasalic@gmail.com
}

\begin{abstract}
The paper presents the results of a research dealing with the independent cultural scene of the city of Zadar, whereby the emphasis was placed on the spatial aspects of independent culture's functioning. The continuing efforts of the scene's actors to achieve their right to space, and thus their right to the city, are perceived from the theoretical perspective of critical urban theory. In accordance with its cultural, artistic and societal agency, often characterized by activist and progressive practices, the independent cultural scene is perceived as a specific type of civil urban actors. Focusing on the perspectives of the scene's representatives, the purpose of the research was to gain an insight into various aspects of the struggle to achieve the right to the space of functioning. The research employed a qualitative approach in the form of semi-structured interviews and included twenty-one interlocutors. Based on the data coding process, which included the descriptive, thematic and analytical level, the research results were organized into three thematic units: space as a usable resource, space as a market resource and the role of public policies. The results indicate that the spatial problematic of independent culture delineates broader mechanisms of the relation towards spatial resources and space as a public good, thus further confirming its societal relevance.
\end{abstract}

Key words: independent cultural scene, the right to the city, urban actors, Zadar. 